\title{
ASSESSMENT OF WATER CONTAMINATION IN FLUVIAL ECOSYSTEMS OF THE THRACE REGION (TURKEY) BY MEANS OF WATER QUALITY INDEX AND GEOGRAPHIC INFORMATION SYSTEM TECHNOLOGY
}

\author{
Cem Tokatli ${ }^{1}$, Alper Uğurluoğlu² \\ ${ }^{1}$ Trakya University, Evrenos Gazi Campus, Laboratory Technology Program, İpsala/Edirne, Turkey \\ ${ }^{2}$ General Directorate of Water Management, Republic of Turkey Ministry of Agriculture and Forestry, Ankara, Turkey
}

\begin{abstract}
Aim of the study

Thrace Region is the most important geographical region of Turkey in terms of agricultural and industrial production. Meriç - Ergene River Basin is the main watershed of this significant region and there are many streams feeding the basin. In the current research, water quality in the fluvial ecosystems of the Thrace Region was evaluated by using some ecological and statistical indicators.
\end{abstract}

\section{Material and methods}

For each water sample, 27 physical and chemical limnological parameters (EC, TDS, turbidity, $\mathrm{NO}_{3}, \mathrm{NO}_{2}$, $\mathrm{SO}_{4}, \mathrm{~F}, \mathrm{COD}, \mathrm{BOD}_{5}$, As, $\mathrm{Se}, \mathrm{Cu}, \mathrm{Zn}, \mathrm{Cd}, \mathrm{Sb}, \mathrm{Ba}, \mathrm{Pb}, \mathrm{B}, \mathrm{Na}, \mathrm{Mg}, \mathrm{Cr}, \mathrm{Mn}, \mathrm{Al}, \mathrm{K}, \mathrm{Ca}, \mathrm{Fe}, \mathrm{Ni}$ ) were analysed and all the investigated parameter values were used to develop the Water Quality Index (WQI). Furthermore, Cluster Analysis (CA) was applied to detected data in order to classify the investigated locations and also Geographic Information System (GIS) was used to provide a visual summary of contamination levels in the basin components.

\section{Results and conclusions}

The results show quite high WQI coefficients of COD (20.773), Se (9.667) and BOD 5 (9.216) parameters in fluvial components of the Thrace Region. The WQI values of the fluvial habitats of the Thrace Region ranged from 33.91 - 329.84, whereas the Çorlu Stream and the Ergene River were determined to be the most contaminated fluvial ecosystems. According to the results of applied CA, 2 statistically significant clusters were formed, which were classified as "High Contaminated Zones" and "Low Contaminated Zones".

Keywords: Thrace Region, Fluvial Ecosystems, Water Quality Index, Cluster Analysis, Geographic Information System

\section{INTRODUCTION}

Thrace Region, which is located in the northwest part of Turkey, has a great potential in terms of agriculture and industry, because of its fertile lands, many freshwater resources, and logistical accessibility. Although it covers about $3 \%$ part of Turkey, about $15 \%$ of the total population lives in this region. Population density and urbanization as well as intensive agricultural and industrial activities cause significant environmental problems in the region (Özler and Aydın, 2008; Sar1 et al., 2016; Tokatli et al., 2020).

\footnotetext{
凶e-mail: tokatlicem@gmail.com
} 
Pollution in freshwater habitats has been a major problem, and new techniques are being applied in order to assess the synergic effects of contaminants. Water quality assessment indices have been used to determine the adverse effects of pollutants in water resources (Ustaoğlu and Tepe, 2019; Varol 2019, Saleem et al., 2019;). Water Quality Index (WQI), which has achieved increasing significance in the management of freshwater resources, is widely used for the evaluation of freshwater qualities of many different aquatic habitats (Sutadian et al., 2016). Describing the suitability of freshwater resources for domestic use especially in terms of WQI is one of the most convenient ways to describe the current water quality. WQI also enables the modifications of policies by various environmental agencies (Akoteyon et al., 2011; Karakuş, 2019; Ustaoğlu and Aydın, 2020).

Multi-statistical techniques, which have been used to evaluate and characterize the freshwater resources, facilitate the interpretation of complex data matrices in order to better understand the ecological statuses of the investigated aquatic habitats. Cluster Analysis (CA), which is grouping the objects based on the similar characteristics they possess, is known as one of the most convenient multivariate statistical methods (Akın et al., 2011; Varol et al. 2012; Belkhiri and Narany, 2015; Köse et al., 2018; Tokatl1, 2020).

Geographic Information System (GIS), which is another powerful tool for spatial analysis, provides a visual summary of lots of investigated physical chemical data, and it also provides an estimation of the pollutant concentrations in locations that lack measurement data (Vairavamoorthy et al., 2007; Yan et al., 2015; Gharbia et al., 2016; Karakus, 2019).

In this research, water quality of fluvial habitats in the Thrace Region - including a total of 2 main rivers of the region and 10 significant tributaries of the basin - was assessed by using WQI, CA, and GIS. In the present investigation, some pollution parameters are preferred, such as nitrate, nitrite, phosphate, sulphate, fluoride, BOD, COD and some inorganic minerals (B, $\mathrm{Na}, \mathrm{Mg}, \mathrm{K}, \mathrm{Ca}, \mathrm{Mn}, \mathrm{Fe}, \mathrm{Se}, \mathrm{Cu}, \mathrm{Zn}$ ), which we believe to best reflect the agricultural pressure that the basin is exposed to. Also some pollution parameters are selected such as heavy metals $(\mathrm{Cd}, \mathrm{As}, \mathrm{Pb}, \mathrm{Ni}, \mathrm{Cr}, \mathrm{Sb}, \mathrm{Ba})$, which we believe to best reflect the industrial pressure to that the basin is exposed to.

\section{MATERIALS AND METHODS}

\section{Study Area}

Meric - Ergene River Basin is located in the Thrace region of Turkey. The Ergene River arises from the Istranca Mountains in the north-east part of Thrace Region and it flows in the northeast-southwest direction. Then it joins the Meriç River and enters the sea at the Saroz Bay. The total surface area of the river basin is $14,510 \mathrm{~km}^{2}$, which covers approximately $1.8 \%$ of the total surface area of Turkey (Technical Assistance for Transformation... 2018).

The average height of the Meriç - Ergene River Basin is ca. $130 \mathrm{~m}$ and the Yildız Mountains with a height of $1000 \mathrm{~m}$ determine the northern border of the basin, while the hills of approximately $400 \mathrm{~m}$ located in the Keşan - Malkara - Hayrabolu Districts determine its southern border. Although it is a peninsula, the Thracian Terrestrial Climate (summers are hot and dry, winters are cold) is dominant within the basin. The average annual precipitation in the Meriç - Ergene River Basin is approximately $665 \mathrm{~mm}$ per year, and the majority of the precipitation is observed in winter season (Status Assessment Report..., 2017; Technical Assistance for Transformation... 2018).

The basin soils are very suitable for agriculture, whereas approximately $26 \%$ of the total Meriç - Ergene River Basin area is forest and scrubland, while approximately $65 \%$ is used as agricultural land. Industry is another significant development tool for the Thrace Region, and the registered number of industrial facilities reached 3409 in 2015, compared to 643 in $1995.82 \%$ of all facilities are located in Tekirdağ Province, $10 \%$ in Kirklareli Province, and 8\% in Edirne Province (Status Assessment Report... 2017).

It is a known fact that the Meriç - Ergene River Basin is under a significant pressure from point source pollution (sourced from industry in general) and nonpoint source pollution (sourced from agriculture in general). It has been reported that point source pollution pressure factors affect approximately $38.7 \%$ of the total surface water mass of the basin, while nonpoint source pollution pressure factors affect approximately $93 \%$ of the total surface water mass of the basin. In addition, water withdrawals for 
agricultural purposes are also known to constitute a significant pressure factor for the basin, and it has been reported that the surface water mass exposed to significant water withdrawal pressures constitutes approximately $25.6 \%$ of the total water mass of the basin. Physical or morphological changes in a river or in a lake may lead to habitat damage resulting in species decline or extinction. Morphological pressure is another threat to the basin, and it has been established that the surface water mass exposed to morphological pressure constitutes approximately $11 \%$ of the total water mass of the basin (Tokatl and Baştatl1, 2016; Technical Assistance for Transformation...2018; Tokatl1, 2019a).

\section{Sample Collection}

21 stations (9 locations on the Ergene River, 2 locations on the Meriç River, and 10 locations downstream of 10 significant tributaries) were selected within the basin, and the names of selected fluvial components are given in Table 1. The topographic map of study area and sampling zones are listed in Figure 1.

The locations on the Ergene River, which is known as the lifeblood of the Thrace Region, were selected from the source, middle, and downstream areas of the river by taking into account the significant contamination factors such as industry, agriculture and settlements, as well as unpolluted regions. The locations on the Meriç River, which is one of the longest rivers in the Balkans, were selected before and after the inflow of the Ergene River in order to present the impact of the Ergene River on the Meriç River. The locations on the 10 significant tributaries of the Ergene River were selected within the downstream regions in order to present the total pollution loads they are carrying to the Ergene River.

Freshwater samples were collected at a depth of $0.5 \mathrm{~m}$ below the water surface in $1 \mathrm{~L}$ pre-cleaned glass bottles. Water samples in triplicates were collected at each site by random sampling. They were also collected from the middle of the streams as much as possible in spring season of 2018. One surface water sample was taken from each selected station, and sampling was performed once. Each water container was clearly marked with the name and date of sampling. Then the samples were stored at $4^{\circ} \mathrm{C}$ in darkness until the chemical analysis.
Table 1. Information of the sampled locations within the basin

\begin{tabular}{|c|c|c|c|}
\hline Code & $\begin{array}{l}\text { Name of the } \\
\text { watercourse }\end{array}$ & Code & $\begin{array}{l}\text { Name of the } \\
\text { watercourse }\end{array}$ \\
\hline E1 & \multirow{9}{*}{ Ergene River } & T1 & Safaalan Creek \\
\hline E2 & & $\mathrm{T} 2$ & Çorlu Stream \\
\hline E3 & & T3 & Ahmetbey Creek \\
\hline E4 & & $\mathrm{T} 4$ & Köprüaltı Creek \\
\hline E5 & & T5 & Ana Creek \\
\hline E6 & & T6 & Hayrabolu Stream \\
\hline E7 & & $\mathrm{T} 7$ & Büyükdere Creek \\
\hline E8 & & $\mathrm{T} 8$ & Kuleli Stream \\
\hline E9 & & T9 & Ana Stream \\
\hline M1 & \multirow{2}{*}{ Meriç River } & $\mathrm{T} 10$ & Irrigation Canal \\
\hline M2 & & & \\
\hline
\end{tabular}

\section{Physicochemical Parameters}

Electrical conductivity (EC), total dissolved solids (TDS), and turbidity parameters were measured with a Hach Lange Branded - HQ40D model Multiparameter Device and a Hach Lange Branded - 2100Q model Portable Turbidimeter Device during the field studies. Nitrate $\left(\mathrm{NO}_{3}\right)$, nitrite $\left(\mathrm{NO}_{2}\right)$, sulphate $\left(\mathrm{SO}_{4}\right)$, fluoride $(\mathrm{F})$, chemical oxygen demand (COD), and biological oxygen demand $\left(\mathrm{BOD}_{5}\right)$ parameters were measured with a Hach Lange Branded - DR890 model Colorimeter Device, a Hach Lange Branded - DR3900 model Spectrophotometer Device, and a Hach Lange Branded - BOD Trak II model Respirometric BOD Devices during the laboratory studies. All the physicochemical analyses was performed following the standard method of APHA (2005).

\section{Chemical Analysis}

The $\mathrm{pH}$ values of water samples (one liter) were set to 2 by means of adding $2 \mathrm{ml}$ of $\mathrm{HNO}_{3}$ into each. Then the water samples were filtered (using a cellulose nitrate $0.45 \mu \mathrm{m}$ filter), and their volumes brought up to $50 \mathrm{ml}$ with ultrapure water. Macro and micro element concentrations (As, $\mathrm{Se}, \mathrm{Cu}, \mathrm{Zn}, \mathrm{Cd}, \mathrm{Sb}, \mathrm{Ba}, \mathrm{Pb}, \mathrm{B}, \mathrm{Na}, \mathrm{Mg}$, $\mathrm{Cr}, \mathrm{Mn}, \mathrm{Al}, \mathrm{K}, \mathrm{Ca}, \mathrm{Fe}, \mathrm{Ni}$ ) were determined by using an Agilent $7700 \mathrm{xx}$ ICP - MS in the central laboratory of Trakya University, which has an accreditation certificate. The macro and micro element analyses were performed by means of a triple measurement (TS EN / ISO IEC 17025) (EPA, 2001). The accuracy of analytical method was determined by testing certified reference material (CRM) (CPAchem - Ref Num: 110580.L1). 
Tokatli, C., Uğurluoğlu, A. (2020). Assessment of Water Contamination in Fluvial Ecosystems of the Thrace Region (Turkey) by Means of Water Quality Index... Acta Sci. Pol., Formatio Circumiectus, 19 (3), 29-42. DOI: http://dx.doi.org/10.15576/ASP.FC/2020.19.3.29

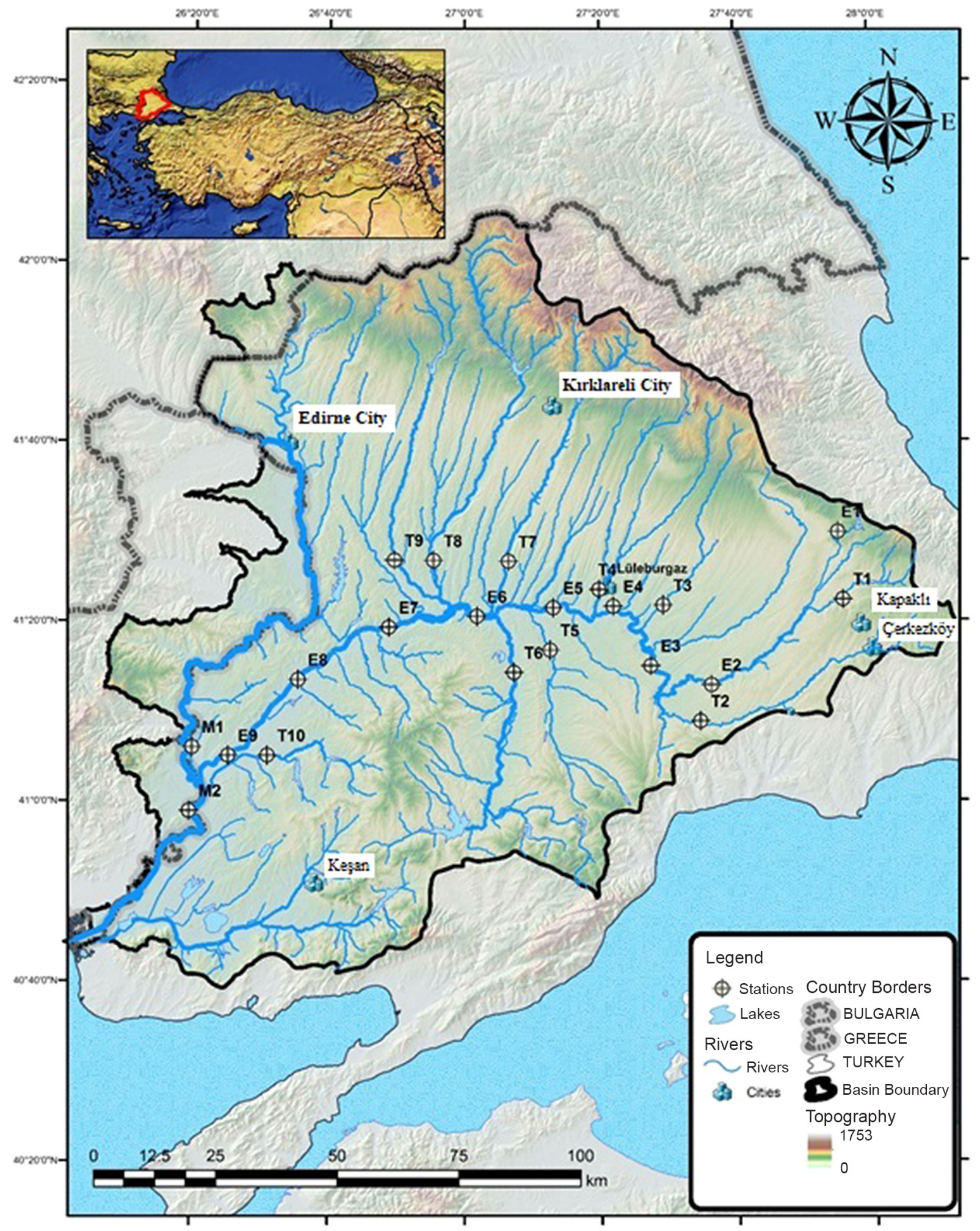

Fig. 1. Topographic map of Thrace Region and sampling zones (Author: Alper Uğurluoğlu) 


\section{Statistical Analysis}

Cluster Analysis was used in the present research, by applying the "PAST" statistical package program for classifying the investigated locations according to the applied Water Quality Index $(W Q I)$ scores.

\section{GIS Based Analysis}

Within the scope of this research, Geographical Information System (GIS) was actively used in all stages of water quality data collection, storage, analysis, and evaluation. The geographic information of the stations, whose coordinate information was obtained with the portable GPS device, was stored as a layer in the geographical database made specifically for this investigation using ArcGIS Software (10.6 Version).

Stream network and basin boundary data were generated with the $30 \mathrm{~m}$ resolution Advanced Spaceborne Thermal Emission and Reflection Radiometer (ASTER) digital elevation model. However, thematic maps showing the water quality in the study area were prepared by using these data and layers obtained from open sources. The basis for these thematic maps is the point representation of the stations according to the Water Quality Index class boundary values, and the stream network representation obtained by using the ArcHYDRO tool that is an extension of the ArcGIS software.

The Stream network (Hydro Network) has been made in the geographic database as a layer that shows the water drainage lines produced according to topological rules in the GIS environment. This dataset will allow analysis of upstream-downstream relationships with other layers produced as Hydro Edges and Hydro Junctions. From this point of view, the water quality data obtained at the stations were accepted as representing all the upstream water drainage lines, and a thematic map was produced by stream network analyses.

\section{Water Quality Index (WQI)}

WQI is an effective technique, widely used in assessing water quality (Wang et al., 2017; Tokatl1, 2019b; Ustaoğlu et al., 2020). The mathematical formula used to calculate the WQI of investigated freshwater habitats is given below:

$$
W Q I=\sum\left[W_{I} \times\left(\frac{C_{i}}{S_{i}}\right) \times 100\right]
$$

$$
W_{I}=\frac{W_{i}}{\Sigma W_{i}}
$$

" $W_{I}$ " is the relative weight, and $W_{i}$ values are assigned a minimum of 1 and a maximum of 5, considering the relatively important effects of parameters on human health. " $C_{i}$ " is the parameter value measured in water. " $S_{i}$ " values refer to the limit values determined by WHO (2011) for drinking water. Standard values $\left(S_{i}\right)$ of the investigated parameters with the assigned $W_{i}$ coefficients in the present application are given in Table 2.

Table 2. Standard values, assigned weights, and relative we-

\begin{tabular}{|c|c|c|c|c|}
\hline Variable & Unit & $\begin{array}{c}\text { Standard } \\
\text { Value } \\
\left(S_{i}\right)\end{array}$ & $\begin{array}{c}\text { Assigned } \\
\text { Weight } \\
\left(W_{i}\right)\end{array}$ & $\begin{array}{c}\text { Relative } \\
\text { Weight } \\
\left(W_{I}\right)\end{array}$ \\
\hline $\mathrm{EC}$ & $\mu \mathrm{S} / \mathrm{cm}$ & 1500 & 3.5 & 0.039 \\
\hline TDS & $\mathrm{mg} / \mathrm{L}$ & 1000 & 3.5 & 0.039 \\
\hline Turbidity & NTU & 5 & 2.5 & 0.028 \\
\hline Nitrate & $\mathrm{mg} / \mathrm{L}$ & 50 & 3.5 & 0.039 \\
\hline Nitrite & $\mathrm{mg} / \mathrm{L}$ & 0.5 & 3.5 & 0.039 \\
\hline Sulphate & $\mathrm{mg} / \mathrm{L}$ & 250 & 2.5 & 0.028 \\
\hline Fluoride & $\mathrm{mg} / \mathrm{L}$ & 1.5 & 2 & 0.022 \\
\hline COD & $\mathrm{mg} / \mathrm{L}$ & 10 & 3 & 0.033 \\
\hline $\mathrm{BOD}_{5}$ & $\mathrm{mg} / \mathrm{L}$ & 5 & 3 & 0.033 \\
\hline B & $\mathrm{ppb}$ & 1000 & 2.5 & 0.028 \\
\hline $\mathrm{Na}$ & $\mathrm{ppb}$ & 50000 & 2 & 0.022 \\
\hline $\mathrm{Mg}$ & ppb & 50000 & 2 & 0.022 \\
\hline $\mathrm{Al}$ & ppb & 200 & 2.5 & 0.028 \\
\hline $\mathrm{K}$ & $\mathrm{ppb}$ & 12000 & 2 & 0.022 \\
\hline $\mathrm{Ca}$ & $\mathrm{ppb}$ & 75000 & 2 & 0.022 \\
\hline $\mathrm{Cr}$ & $\mathrm{ppb}$ & 50 & 4.5 & 0.050 \\
\hline $\mathrm{Mn}$ & $\mathrm{ppb}$ & 50 & 4 & 0.044 \\
\hline $\mathrm{Fe}$ & $\mathrm{ppb}$ & 200 & 3.5 & 0.039 \\
\hline $\mathrm{Ni}$ & $\mathrm{ppb}$ & 20 & 4.5 & 0.050 \\
\hline $\mathrm{Cu}$ & $\mathrm{ppb}$ & 2000 & 3 & 0.033 \\
\hline $\mathrm{Zn}$ & $\mathrm{ppb}$ & 3000 & 3 & 0.033 \\
\hline As & $\mathrm{ppb}$ & 10 & 5 & 0.056 \\
\hline $\mathrm{Se}$ & $\mathrm{ppb}$ & 10 & 4 & 0.044 \\
\hline $\mathrm{Cd}$ & ppb & 3 & 5 & 0.056 \\
\hline $\mathrm{Sb}$ & ppb & 5 & 5 & 0.056 \\
\hline $\mathrm{Ba}$ & $\mathrm{ppb}$ & 700 & 3.5 & 0.039 \\
\hline $\mathrm{Pb}$ & $\mathrm{ppb}$ & 10 & 5 & 0.056 \\
\hline
\end{tabular}
ights of parameters 


\section{RESULTS}

Monomial and multinomial risks according to WQI for all the investigated fluvial ecosystems of the Thrace Region were calculated separately. Basin distribution map of WQI scores made by using GIS technology is given in Figure 2. The elemental and limnologic contamination rates of investigated parameters were plotted on a GIS based map and presented in Figure 3. The quality classes of investigated locations according to the detected WQI scores were shown on a GIS based map and given in Figure 4. Also all the calculated monomial WQI coefficients of each locations and parameters are listed in Figure 5.

As a results of the applied WQI, the detected index scores were recorded between 33.91 (the source of Ergene River - "Excellent") - 329.84 (Çorlu Stream - "Unsuitable"), and the middle stream of Ergene River and the Çorlu Stream were recorded as the most contaminated zones among the investigated fluvial habitats in the Thrace Region of Turkey. The recorded WQI scores detected in the middle stream of Ergene River and detected in the Corlu Stream were approximately 2 and 4 times above the recorded fluvial averages of the region (89.34), respectively.

Upstream of Ergene River (E1 - WQI: 33.914), Meriç River (M1 and M2 - WQIs: 38.388 and 40.961 respectively), Ahmetbey Creek (T3 - WQI: 34.148) Köprüaltı Creek (T4 - WQI: 40.643), Ana Creek (T5 - WQI: 46.614), Hayrabolu Stream (T6 - WQI: 44.433), Büyükdere Creek (T7 - WQI: 47.156), Kuleli Stream (T8 - WQI: 38.101) and Ana Stream (T9 - WQI: 46.974) have "excellent" and "A grade" water quality; Safaalan Creek (T1 - WQI: 57.164), Irrigation Canal (T10 - WQI: 55.981) and middle stream of Ergene River (E7, E8 and E9 - WQIs: 84.381, 63.076 and 52.198 respectively) have "good" and "B grade" water quality, down stream of Ergene River (E2, E3, E4, E5 and E6 - WQIs: 152.379, 213.912, 185.588, 158.226 and 112.187 respectively) have "poor - very poor" and "C - D grade" water quality; and Çorlu Stream (T2 - WQI: 329.842) has "unsuitable" and "E grade" water quality.

As a result of monomial variables of WQI, the mean detected index scores of investigated parameters were recorded between $0.017(\mathrm{Cu})-20.773$ (COD) whereas $\mathrm{COD}, \mathrm{Se}$ and $\mathrm{BOD}_{5}$ parameters were found to be the variables of the highest risk (WQI: 20.773, 9.667 and 9.216 respectively) for the investigated fluvial habitats of the Thrace Region. The recorded mean WQI coefficients for COD, Se and $\mathrm{BOD}_{5}$ in the basin were approximately $6.5,3$ and 2.5 times above the recorded monomial averages of the variables (3.309), respectively. The risks of investigated water quality parameters for fluvial habitats of the Thrace Region may be listed as $\mathrm{COD}>\mathrm{Se}>\mathrm{BOD}_{5}>$ turbidity $>\mathrm{Na}>$ $\mathrm{Mn}>\mathrm{Fe}>\mathrm{Ni}>\mathrm{Sb}>\mathrm{EC}>\mathrm{TDS}>\mathrm{As}>\mathrm{K}>\mathrm{Cr}>\mathrm{Ca}$ $>\mathrm{SO}_{4}>\mathrm{Mg}>\mathrm{Al}>\mathrm{NO}_{2}>\mathrm{F}>\mathrm{B}>\mathrm{Ba}>\mathrm{NO}_{3}>\mathrm{Pb}>$ $\mathrm{Cd}>\mathrm{Zn}>\mathrm{Cu}$, in general. As a result of multinomial variables of WQI, the risks of investigated fluvial ecosystems of the Thrace Region may be listed as T2 $>$ $\mathrm{E} 3>\mathrm{E} 4>\mathrm{E} 5>\mathrm{E} 2>\mathrm{E} 6>\mathrm{E} 7>\mathrm{E} 8>\mathrm{T} 1>\mathrm{T} 10>\mathrm{E} 9$ $>\mathrm{T} 7>\mathrm{T} 9>\mathrm{T} 5>\mathrm{T} 6>\mathrm{M} 2>\mathrm{T} 4>\mathrm{M} 1>\mathrm{T} 8>\mathrm{T} 3>$ E1, in general.

Cluster Analysis (CA) was applied to the detected data in order to determine the similar groups among the investigated fluvial habitats in the Thrace Region according to the WQI scores. The diagram of CA is given in Figure 6. According to the results of CA, 2 clusters were identified, which were named "more contaminated zones" and "less contaminated zones". The higher pollution risk cluster (C1) was formed by the locations of the upper and lower streams of the Ergene River (E1, E8 and E9 stations), the Meriç River (M1 and M2 stations) and all the other investigated tributaries except the Çorlu Stream (T1, T3, T4, T5, T6, T7, T8, T9 and T10 stations); whereas the lower pollution risk cluster (C2) was formed by the locations in the midstream of the Ergene River (E2, E3, E4, E5, E6 and E7 stations) and the Çorlu Stream (T2 station). 


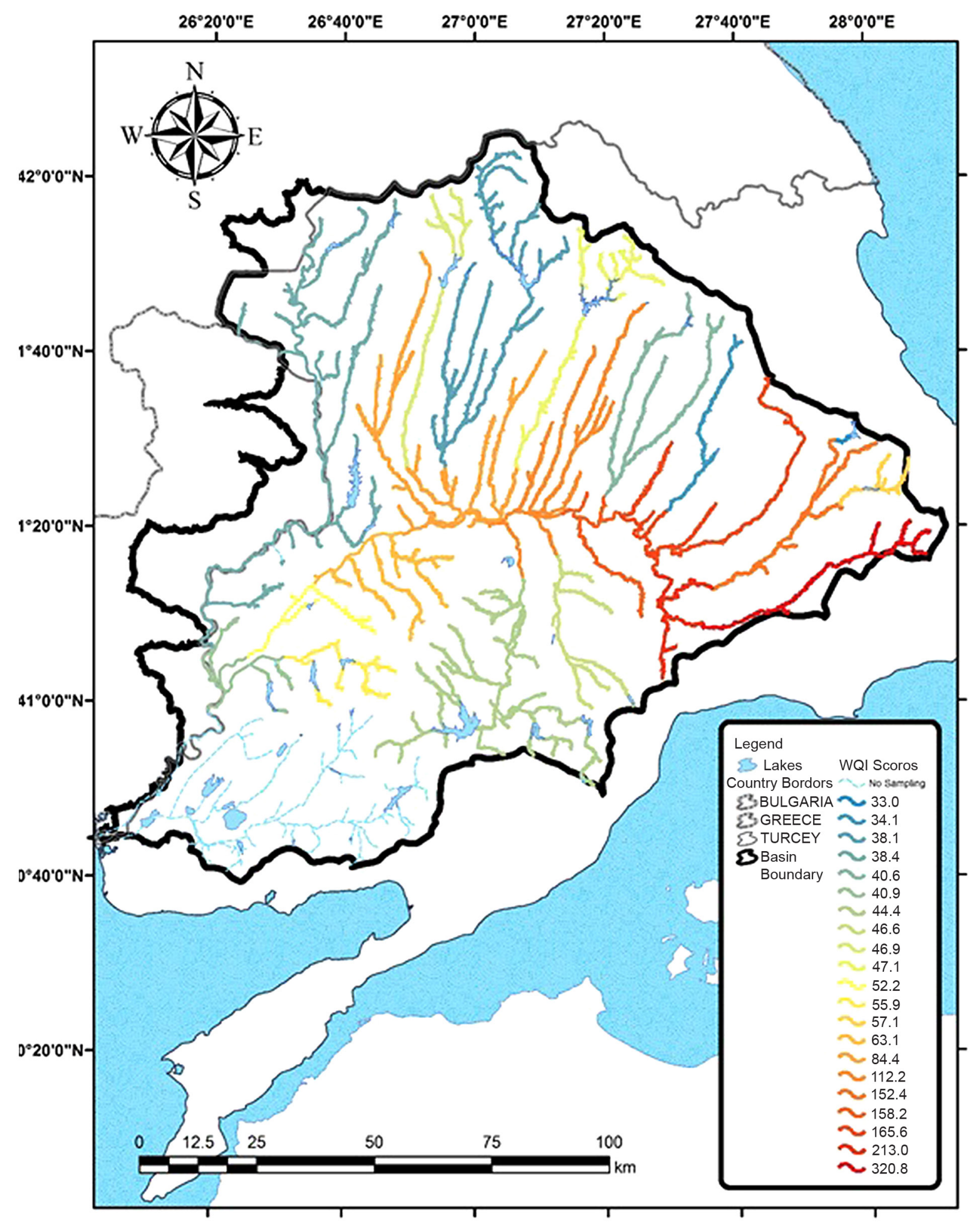

Fig 2. GIS maps of spatial variations of WQI scores (Author: Alper Uğurluoğlu) 


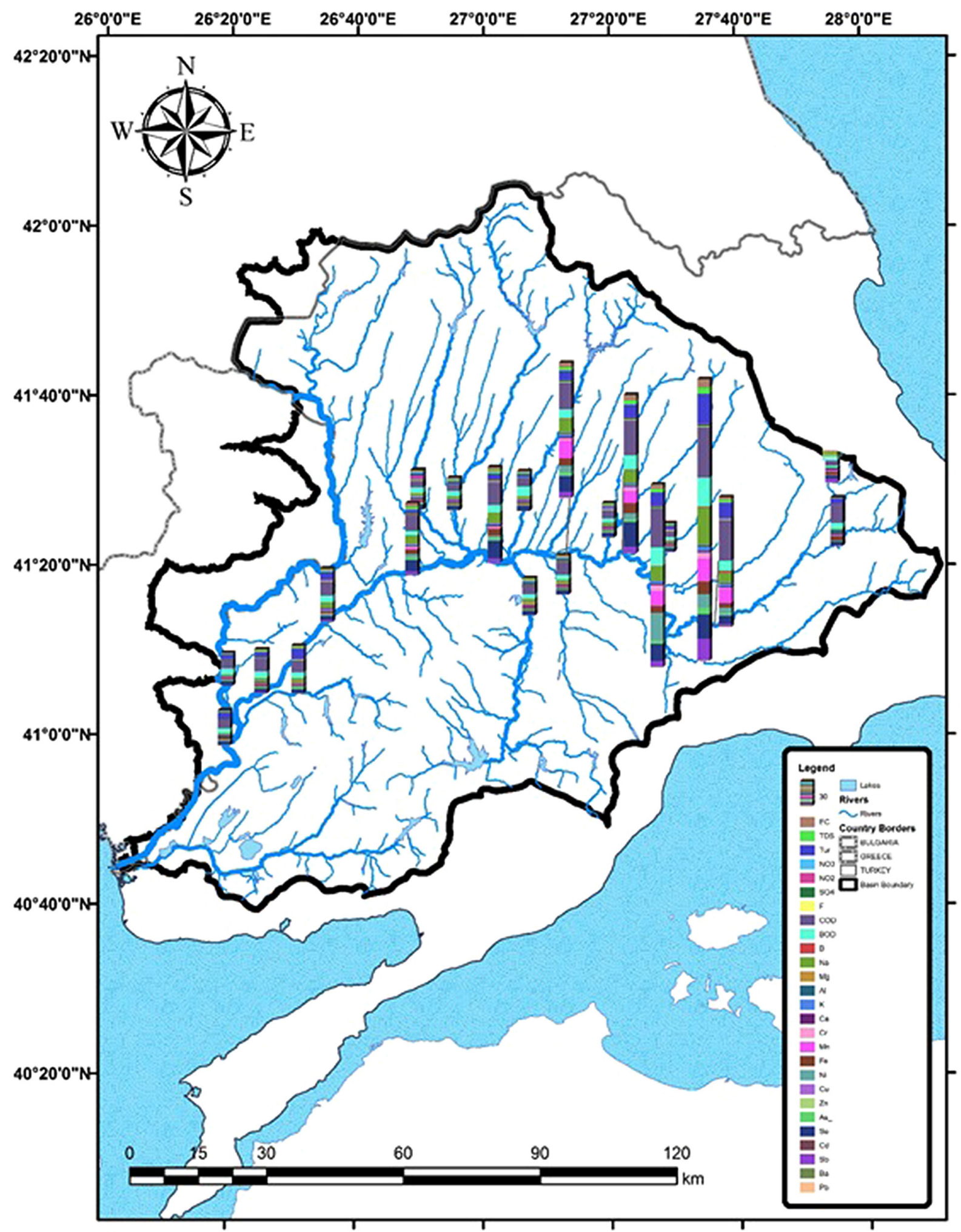

Fig 3. GIS maps of contamination rates of investigated parameters (Author: Alper Uğurluoğlu) 


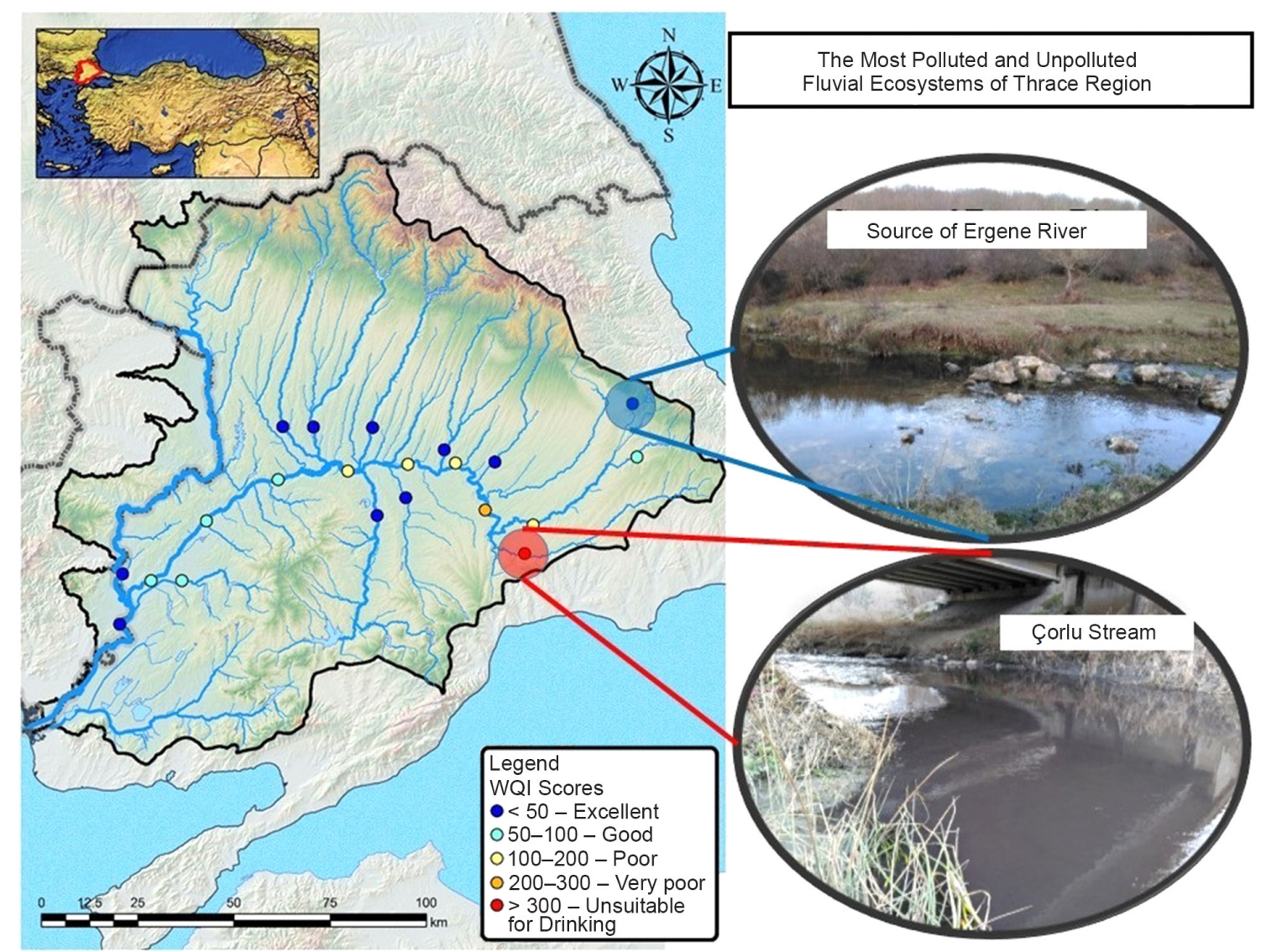

Fig 4. GIS maps of quality classes of investigated locations (Authors: Alper Uğurluoğlu and Cem Tokatli)

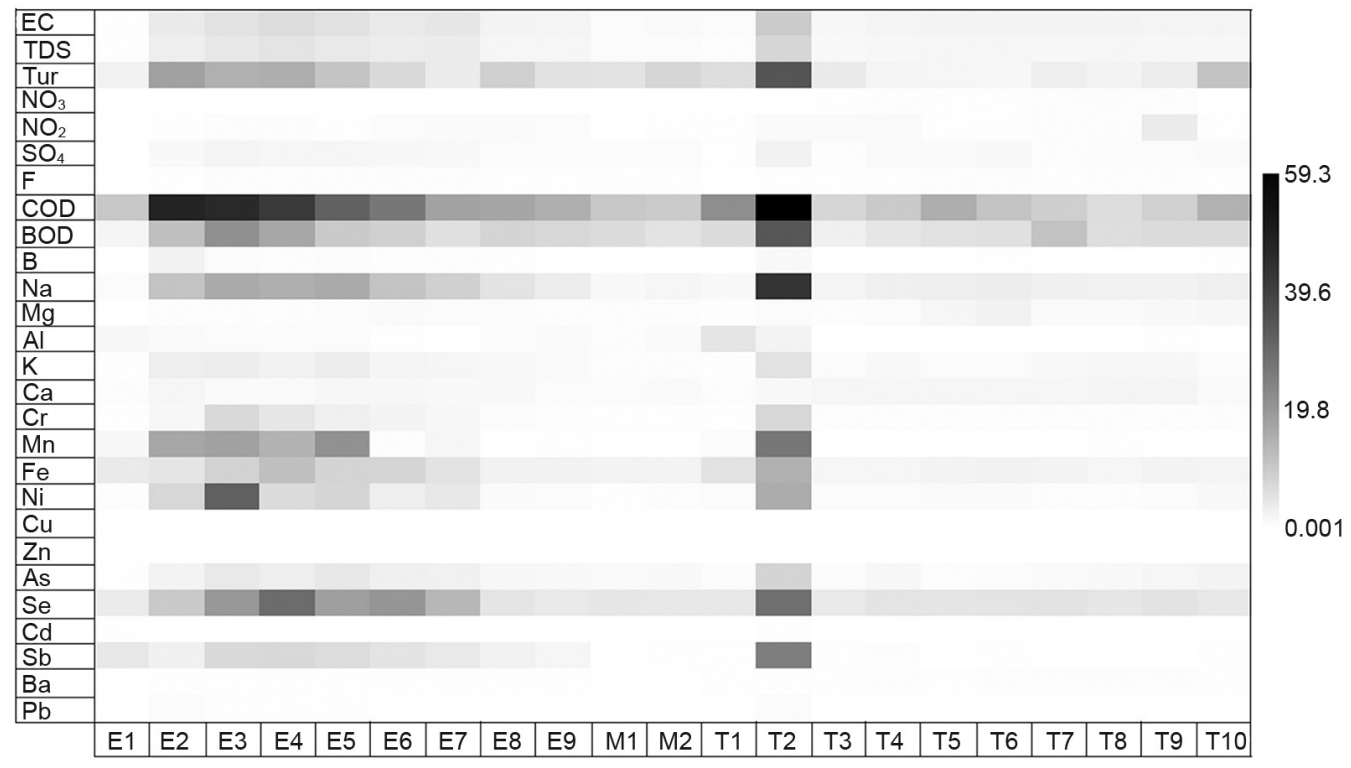

Fig. 5. Monomial WQI scores of investigated locations and parameters (Author: Cem Tokatli) 


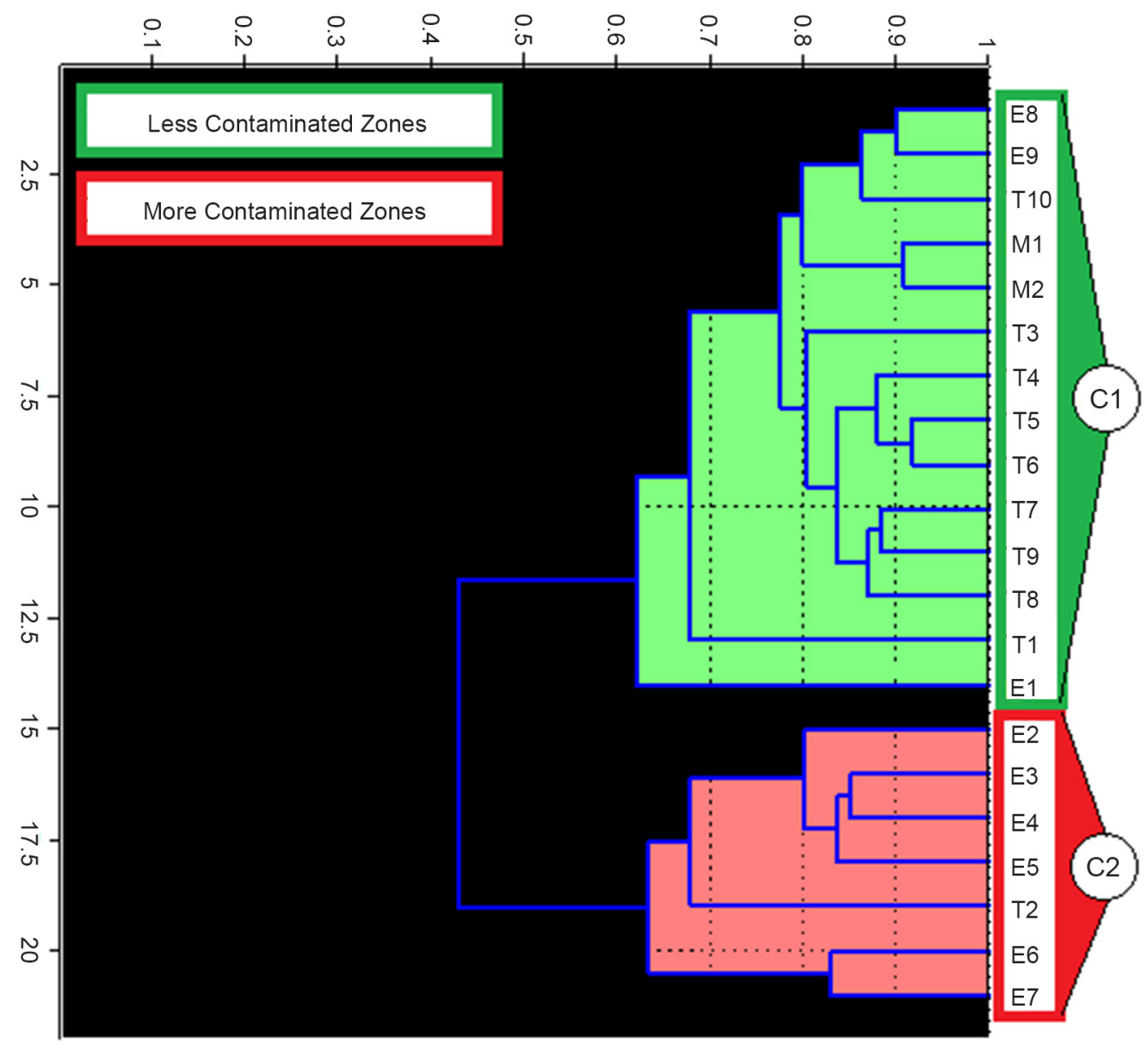

Fig. 6. CA diagram (Author: Cem Tokatli)

\section{DISCUSSION}

In the present research, Water Quality Index (WQI) and Geographic Information System (GIS) technology were used to evaluate freshwater quality of Turkey's Thrace Region. As a result of the study, Çorlu Stream and Ergene River were found to be the most contaminated aquatic ecosystems, whereas COD, Se, $\mathrm{BOD}_{5}$ and turbidity parameters were found to be the variables of the highest risk to the region's waters.

It is known that selenium may enter the surface water by means of irrigation drainage waters, and accumulation of selenium in agricultural drainage waters has been documented in many basins. Also some scientific evidence shows that selenium may bio-accu- mulate in the tissues of many aquatic organisms, and possibly this may significantly increase the rates in the food chain (ATSDR, 2003; Tokatl1, 2019b). Therefore, although selenium is an essential element, high levels of selenium in water may cause significant environmental and health problems.

In the present research, selenium parameter was recorded as the second highest variable in terms of risk according to the detected WQI scores. Thrace Region, which constitutes one of the most productive agricultural lands of Turkey, has a great agricultural potential as it contains rich soils and many freshwater resources. About $95 \%$ of the region (over one million hectares) is suitable for agriculture (TZOB, 2003; Edirne İl Cevre Durum Raporu..., 2005). Intensive agricultural appli- 
cations conducted all around the region are thought to be the main cause of the relatively high selenium risk detected, and the results of this study show that the fluvial habitats of the region are significantly affected by agricultural applications.

Thrace Region is also known as an important industry zone, in addition to the productive agricultural lands. There are many industrial enterprises, particularly in the east part of the region within the borders of Ergene River Basin, notably the Çerkezköy, Çorlu, Lüleburgaz and Muratl districts. Thrace Region, especially in terms of the textile industry, is one of Turkey's most important industrial regions (Hall et al., 2014; Tokatlı and Baştatlı, 2016; Tokatlı 2017; 2018; 2019c; Kahraman and Özkul, 2018). Textile companies, which are very numerous in the region, consume significant amounts of water through many operations, like dyeing, washing, scouring, and bleaching. In addition to the consumed water, they also use some dyes and salts and many other auxiliaries in the process. A direct release of the textile effluent that contains high levels of organic and inorganic materials, total suspended solids (TSS), biochemical oxygen demand $\left(\mathrm{BOD}_{5}\right)$, and chemical oxygen demand (COD) into watercourses leads to significant environmental contamination. These applications cause highly coloured effluent and an increase of many pollutants (Jayakkodi et al., 2016; Ramesh et al., 2017).

In the present research, it was determined that the parameters of $\mathrm{COD}, \mathrm{BOD}_{5}$ and turbidity were among the highest risk variables according to the detected WQI scores. In addition, the Çorlu Stream and the Ergene River, where the industrialisation is the most intense of the whole region, were found to be at the highest risk, as the most contaminated fluvial habitats. These results reflect the fact that the fluvial ecosystems of the Thrace Region, especially the Çorlu Stream and the Ergene River are intensively affected by industrial activities, especially of the textiles companies.

The salinization in surface water and groundwater is a serious problem that is limiting irrigation and domestic use of freshwater. EC and TDS variables are the two most important parameters that reveal the salinity of freshwater (Wetzel, 2001; Manahan, 2011). The main anthropogenic sources of freshwater salinization are known as wastewater with a high salt content, in- creased evaporation and decreased precipitation, irrigation of dry areas with lack of proper drainage, and intensive groundwater pumping (Foster and Chilton, 2003; Colombani et al., 2016). In the present research, the monomial loads of EC and TDS variables in the application of WQI ranged from 0.389 to 9.722 , and from 0.338 to 7.544 , respectively. The highest coefficients of EC and TDS were recorded in the Çorlu Stream and in the middle stream of Ergene River, that is the areas that were exposed to significant industrial pressure. EC and TSD coefficients of the Çorlu Stream and the middle stream of Ergene River ranged approximately 3 and 2 times above the recorded basin averages for EC (3.004) and TDS (2.377) variables, respectively.

Nitrate, nitrite and sulphate parameters are considered the main indicators of pollution caused by agricultural activities (Wetzel, 2001; Manahan, 2011). In the present WQI application for the fluvial water ecosystems of the Thrace Region, although agricultural activities are quite intense in the region, these parameters were not found to be significant risk factors, due to their having low toxicities compared to heavy metals, and presenting relative high standard values used in WQI calculations.

In a study performed in the catchments of the Emet and Orhaneli Streams, mining stress and water quality of the basin were evaluated with the use of WQI. According to the results of this investigation, similarly as in the present research, the general trend of WQI for the Emet and Orhaneli Streams was determined as heavily polluted water quality (WQI > 300) (Omwene et al., 2019).

In another research conducted in the Turnasuyu Stream, northern Turkey, WQI was used to evaluate water quality. In contrast to the current study results, it was determined that the water quality of the Turnasuyu Stream was found to be "A Grade - Excellent" in terms of the applied WQI (Ustaoğlu et al., 2020).

In another investigation performed in the Western Black Sea Basin of Turkey, water quality of the Melen Stream was assessed by using WQI and - similar to the current research results - upstream water quality was recorded as "Medium Grade", and downstream water quality was recorded as "Poor Grade" (Karakaya and Evrendilek, 2010). 


\section{CONCLUSIONS}

In this research, water quality of the lotic freshwater resources of a significant agricultural-industrial region of Turkey were evaluated by using WQI and GIS technology. According to the obtained WQI data, it was determined that approximately $47.6 \%$ of the region's waters were of "excellent" quality (WQI: $<50) ; 23.8 \%$ of the region's waters were of "good" quality (WQI: $50-100) ; 19 \%$ of the region's waters were of "poor" quality (WQI: 100-200); 4.7\% of the region's waters were of 'very poor' quality (WQI: 200-300); and $4.7 \%$ of the region's waters were of "unsuitable" quality (WQI: > 300), in general. It was also determined that the Çorlu Stream and the Ergene River were found as the most contaminated fluvial habitats, and that their $\mathrm{COD}, \mathrm{Se}, \mathrm{BOD}_{5}$ and turbidity were also recorded as the variables of the highest threat to the region's waters. As a result of applied CA, 2 statistically significant clusters were formed for the fluvial habitats of the Thrace Region, which were designated as "High Contaminated Zones", including the middle stream of the Ergene River and the Çorlu Stream, and "Low Contaminated Zones" including the lower and upper streams of the Ergene River, the Meriç River, and almost all of the investigated tributaries.

In conclusion, we suggest that significant precautions should be taken in order to control the input of contaminants into the Ergene River and the Çorlu Stream, and also that poly-cultural agricultural applications need to be supported in order to avoid using intensive chemical fertilizers and pesticides around the region. The study suggests the need for a long-term water quality monitoring of the fluvial habitats of the Thrace Region, and determination of the contamination sites for a proper management of the basin. The results of the present study also reflect the necessity and applicability of WQI and GIS technologies for water quality assessment investigations.

\section{ACKNOWLEDGEMENT}

This study was financially supported by a scientific research project in Trakya University (project number: 2017/211).

\section{REFERENCES}

Akin, B. S., Atıc1, T., Katircioglu, H., Keskin, F., 2011. Investigation of Water Quality on Gökçeekaya Dam Lake Using Multivariate Statistical Analysis, in Eskişehir, Turkey. Environmental Earth Sciences, 63, 1251-1261.

Akoteyon, I. S., Omotayo, A. O., Soladoye, O., Olaoye, H. O., 2011. Determination of Water Quality Index and Suitability of Urban River for Municipal Water Supply in Lagos-Nigeria. European Journal of Scientific Research, 54, 263-271.

APHA (American Public Health Association), 2005. Standard Methods for Examination of Water and Waste Water. 21st ed. Washington (DC, USA): American Public Health Association.

ATSDR (Agency for Toxic Substances and Disease Registry), 2003. Toxicological Profile for Selenium. Atlanta, GA: U.S. Department of Health and Human Services.

Belkhiri, L., Narany, T. S., 2015. Using Multivariate Statistical Analysis, Geostatistical Techniques and Structural Equation Modeling to Identify Spatial Variability of Groundwater Quality. Water Resources Management, 29, 2073-2089.

Colombani, N., Osti, A., Volta, G., Mastrocicco, M., 2016. Impact of Climate Change on Salinization of Coastal Water Resources. Water Resource Management, 30, 2483-2496.

Edirne İl Çevre Durum Raporu, 2005. Edirne Valiliği İl Çevre Ve Orman Müdürlüğü.

Environmental Protection Agency (EPA) METHOD 200.7., 2001. Determination of Metals and Trace Elements in Water and Wastes by Inductively Coupled Plasma-Atomic Emission Spectrometry.

Erkmen, B., Kolankaya, D., 2006. Determination of Organochlorine Pesticide Residues in Water, Sediment, and Fish Samples from the Meriç Delta, Turkey. International Journal of Environmental Analytical, Chemistry, 86, 161-169.

Foster, S. S. D., Chilton, P. J., 2003. Groundwater: the processes and global significance of aquifer degradation. Phil. Trans. R. Soc. Lond. B. Biological Sciences, 358, 1957-1972.

Gharbia, A. S., Gharbia, S. S., Abushbak, T., Waf, H., Aish, A., Zelenakova, M., 2016. Groundwater Quality Evaluation Using GIS Based Geostatistical Algorithms. Journal of Geoscience and Environment Protection, 4, 89.

Hall1, M., Sarı, E., Kurt, M. A., 2014. Assessment of Arsenic and Heavy Metal Pollution in Surface Sediments of the Ergene River, Turkey. Polish Journal of Environmental Studies, 23(5), 1581-1590. 
Jayakkodi, R., Annadurai, R., 2016. Evaluation of sago effluent water treated and untreated UASB reactor. Asian Journal Chemistry, 28 (6), 1218-1220.

Kahraman, A. C., Özkul, M., 2018. Ergene Havzasi Koruma Eylem Planı Durum Değerlendirme Raporu. Marmara Belediyeler Birliği Çevre Yönetimi Koordinatörlüğü.

Karakaya, N., Evrendilek, F. 2010. Water Quality Time Series for Big Melen Stream (Turkey): Its Decomposition Analysis and Comparison to Upstream. Environmental Monitoring and Assessment, 165, 125-136.

Karakuş, C. B. 2019. Evaluation of Groundwater Quality in Sivas Province (Turkey) Using Water Quality Index and GIS-Based Analytic Hierarchy Process. International Journal of Environmental Health Research, 29(5), 500-519.

Köse, E., Emiroğlu, Ö., Çiçek, A., Tokatl1, C., Başkurt, S., Aksu, S., 2018. Sediment Quality Assessment in Porsuk Stream Basin (Turkey) from a Multi-Statistical Perspective. Polish Journal of Environmental Studies, 27(2), $747-752$.

Manahan, S. E., 2011. Water Chemistry: Green Science and Technology of Nature's Most Renewable Resource. Taylor \& Francis Group, CRC Press, 398 pages.

Omwene, P. I., Öncel, M. S., Çelen, M., Kobya, M., 2019. Influence of Arsenic and Boron on the Water Quality Index in Mining Stressed Catchments of Emet and Orhaneli Streams (Turkey). Environmental Monitoring and Assessment, 191, 199.

Özler, H. M., Aydın, A., 2008. Hydrochemical and Microbiological Quality of Groundwater in West Thrace Region of Turkey. Environmental Geology, 54(2), 355-363.

Ramesh, K., Balakrishnan, M., Vigneshkumar, B., Manju, A., Dhanakumar, S., Palanivel, M., Kalaiselvi, K., 2017. Removal of colour and chemical oxygen demand from textile effluent by Fenton oxidation method. Current Science, 113(11), 2112-2119.

Saleem, M., Iqbal, J., Shah, M. H., 2019. Seasonal Variations, Risk Assessment and Multivariate Analysis of Trace Metals in the Freshwater Reservoirs of Pakistan. Chemosphere, 216, 715-724.

Sari, E., Cukrov, N., Frančišković-Bilinski, S., Kurt, M. A., Halli, M., 2016. Contamination Assessment of Ecotoxic Metals in Recent Sediments from the Ergene River, Turkey. Environmental Earth Sciences, 75, 1051.

Status Assessment Report of Ergene Basin Protection Action Plan. 2017. Marmara Municipalities Union Publications.

Sutadian, A. D., Muttil, N., Yilmaz, A. G., Perera, B. J. C., 2016. Development of River Water Quality Indices A review. Environmental Monitoring and Assessment, 188,58 .
Technical Assistance for Transformation of Basin Protection Action Plans into River Basin Management Plans - Meriç-Ergene River Basin Management Plan. 2018. EuropeAid / 134561 / D / SER / TR.

Tokatl1, C., 2017. Bio - Ecological and Statistical Risk Assessment of Toxic Metals in Sediments of a Worldwide Important Wetland: Gala Lake National Park (Turkey). Archives of Environmental Protection, 43(1), 34-47.

Tokatlı, C., 2018. Essential and Toxic Element Bioaccumulations in Fishes of Gala and Sığırcı Lakes (Meriç River Delta, Turkey). Acta Alimentaria, 47(4), 470-478.

Tokatl1, C., 2019a. Water and Sediment Quality Assessment of the Lifeblood of Thrace Region (Turkey): Meriç River Basin. Fresenius Environmental Bulletin, 28(5), 4131-4140.

Tokatl1, C., 2019b. Drinking Water Quality Assessment of Ergene River Basin (Turkey) by Water Quality Index: Essential and Toxic Elements. Sains Malaysiana, 48(10), 2071-2081.

Tokatl1, C., 2019c. Sediment Quality of Ergene River Basin: Bio - Ecological Risk Assessment of Toxic Metals. Environmental Monitoring and Assessment, 191(11), $1-12$.

Tokatl1, C., 2020. Water Quality Assessment of Ergene River Basin Using Multivariate Statistical Analysis. Journal of Limnology and Freshwater Fisheries Research, 6(1), 38-46.

Tokatlı, C., Baştatlı, Y., 2016. Trace and Toxic Element Levels in River Sediments. Polish Journal of Environmental Studies, 25(4), 1715-1720.

Tokatlı, C., Solak, C. N., Y1lmaz, E., 2020. Water Quality Assessment by Means of Bio-Indication: A Case Study of Ergene River Using Biological Diatom Index. Aquatic Sciences and Engineering, 35(2), 43-45.

TZOB (Türkiye Ziraat Odaları Birliği), 2003. Çeltik Çalışma Grubu Raporu. Say1 1.

Ustaoğlu, F., Aydın, H., 2020. Health Risk Assessment of Dissolved Heavy Metals in Surface Water in a Subtropical Rivers Basin System of Giresun (north-eastern Turkey). Desalination and Water Treatment, 194, 222-234.

Ustaoğlu, F., Tepe, Y., 2019. Water Quality and Sediment Contamination Assessment of Pazarsuyu Stream, Turkey Using Multivariate Statistical Methods and Pollution Indicators. International Soil and Water Conservation Research, 7, 47-56.

Ustaoğlu, F., Tepe, Y., Taş, B., 2020. Assessment of Stream Quality and Health Risk in a Subtropical Turkey River System: A Combined Approach Using Statistical Analysis and Water Quality Index. Ecological Indicators, 113, 105815. 
Vairavamoorthy, K., Yan, J. M., Galgale, H. M., \& Gorantiwar, S. D., 2007. IRA-WDS: A GIS-Based Risk Analysis Tool for Water Distribution Systems. Environmental Modelling \& Software, 22, 951-965.

Varol, M. (2019). Arsenic and trace metals in a large reservoir: Seasonal and spatial variations, source identification and risk assessment for both residential and recreational users. Chemosphere, 228, 1-8.

Varol, M., Gökot, B., Bekleyen, A. \& Şen, B. (2012). Water quality assessment and apportionment of pollution sources of Tigris River (Turkey) using multivariate statistical techniques-A case study. River Research and Applications, 28(9), 1428-1438.

Wang, J., Liu, G., Liu, H., Lamc, P., 2017. Multivariate Statistical Evaluation of Dissolved Trace Elements and a Water Quality Assessment in the Middle Reaches of Huaihe River, Anhui, China. Science of the Total Environment, 583, 421-431.

Wetzel, R. G., 2001. Limnology: Lake and River Ecosystems. Elsevier Academic Press, 1006 pages.

World Health Organization (WHO), 2011. Guidelines for Drinking-water Quality. World Health Organization Library Cataloguing-in-Publication Data, NLM classification: WA 675.

Yan, C. A., Zhang, W., Zhang, Z., Liu, Y., Deng, C., Nie, N., 2015. Assessment of Water Quality and Identification of Polluted Risky Regions Based on Field Observations \& GIS in the Honghe River Watershed, China. Plos One, $10,1-13$.

\section{OCENA ZANIECZYSZCZENIA WODY W EKOSYSTEMACH RZECZNYCH REGIONU TRACJI (TURCJA) ZA POMOCĄ WSKAŹNIKA WOI I TECHNOLOGII SYSTEMU INFORMACJI GEOGRAFICZNEJ}

\section{ABSTRAKT}

\section{Cel pracy}

Tracja to najważniejszy region geograficzny Turcji pod względem produkcji rolnej i przemysłowej. Dorzecze rzek Meriç - Ergene jest głównym działem wodnym tego znaczącego regionu, a zasilają je liczne strumienie. W prezentowanych badaniach jakość wody ekosystemów rzecznych regionu Tracji oceniono przy użyciu wskaźników ekologicznych i statystycznych.

\section{Materiat i metody}

Każdą próbkę wody przebadano pod względem 27 fizycznych i chemicznych parametrów limnologicznych (EC, TDS, zmętnienie, $\mathrm{NO}_{3}, \mathrm{NO}_{2}, \mathrm{SO}_{4}, \mathrm{~F}, \mathrm{ChZT} / \mathrm{COD}, \mathrm{BZT}_{5} / \mathrm{BOD}_{5}$, As, Se, $\mathrm{Cu}, \mathrm{Zn}, \mathrm{Cd}, \mathrm{Sb}, \mathrm{Ba}, \mathrm{Pb}, \mathrm{B}, \mathrm{Na}$, $\mathrm{Mg}, \mathrm{Cr}, \mathrm{Mn}, \mathrm{Al}, \mathrm{K}, \mathrm{Ca}, \mathrm{Fe}, \mathrm{Ni}$ ), a przebadane wartości parametrów posłużyły do wyliczenia wskaźnika jakości wody (WQI). Ponadto do danych zastosowano grupowanie hierarchiczne (analizę klastrów, CA) w celu sklasyfikowania badanych lokalizacji, a także system informacji geograficznej (GIS), który pomógł zwizualizować poziomy zanieczyszczeń w poszczególnych obszarach zlewni.

\section{Wyniki i wnioski}

Uzyskane wyniki wskazują na stosunkowo wysokie współczynniki WQI parametrów ChZT/COD (20,773), Se $(9,667)$ i $\mathrm{BZT}_{5} / \mathrm{BOD}_{5}(9,216) \mathrm{w}$ ciekach wodnych regionu Tracji. Wartości WQI dla siedlisk wodnych regionu Tracji wahały się od 33,91 do 329,84, przy czym potok Çorlu i rzeka Ergene zostały określone jako najbardziej zanieczyszczone ekosystemy rzeczne. Zgodnie z wynikami zastosowanej analizy klastrów utworzono 2 statystycznie istotne klastry, które nazwano „Strefami silnie zanieczyszczonymi” i „Strefami słabo zanieczyszczonymi".

Słowa kluczowe: region Tracji, ekosystemy rzeczne, wskaźnik jakości wody WQI, analiza klastrów (grupowanie hierarchiczne), system informacji geograficznej (GIS) 